гг. часто предвосхищают будущую программу германского фашизма. Так, С. Рудницкий в целях улучшения расы предлагал стерилизацию «малоценных» людей. Столь радикально жестокой меры не предлагали даже члены «Общества Гобино». При этом не конкретизируется, кого считать «малоценным». Можно предполагать, что к «малоценными» относились не только больные люди, но в целом русские, поляки, белорусы, евреи и т.д., поскольку они считались «малоценными расами».

В целом необходимо отметить, что украинский национализм 1920-1930-х гг. лишь в деталях отличается от германского. По содержанию и целям украинский и германский национализм совпадают.

\section{УДК 316.444.56.4}

\section{ТРУДОВЫЕ ПРЕДПОЧТЕНИЯ вУЗОВСКИХ ВЫПУСКНИКОВ}

\section{И.Г. Малинский \\ Саратовский государственный университет \\ E-mail: mig@info.sgu.ru}

В статье по результатам социологического опроса анализируются основные модели трудовых предпочтений выпускников Саратовского университета и выявляется влияние специализации и вторичной занятости студентов на их трудовые стратегии.

Ключевые слова: вторичная занятость студентов, профессиональная специализация, трудовые ориентации выпускников, рынок труда.

\section{Labor Preferences of the Graduates.}

\section{I.G. Malinsky}

In the article the main models of the labor preferences of the Saratov University graduates' were analyzed. The article is written on the base of the social research. The influence of the specialization and second employment upon the graduates' labor strategies was determined. Keywords: student' second employment, professional specialization, graduates' labor orienteer, labor market.

Молодость - это особый этап в жизни каждого человека. Стартовые позиции, достигнутые в самом начале жизненного пути, являются предпосылкой для дальнейшей самореализации. Благодаря развитию системы негосударственного и внебюджетного профессионального образования у молодых людей расширились возможности выбора вида, формы его получения. Расширение свобод выбора в образовательной сфере и увеличение контингента обучающихся в вузах наталкивается на реалии свободного рынка труда, где количество свободных рабочих мест для специалистов с высшим профессиональным образованием ограничено, а требования к претен-

\section{Примечания}

1 Московский комсомолец. 2008. 24 нояб.

2 Рудницкий C. До основ украінського націоналізму. Прага, 1928. С. 15.

3 Там же. С. 56-57.

4 Там же. С. 76.

5 К сожалению, они пришлись по душе и президенту В. Ющенко, который пытался их реанимировать, модернизировать и навязать украинскому народу.

6 Rudnitzkij S. Ukraina. Land und Volk. Wien, 1916. S. 182.

7 Рудницкий C. До основ украінського націоналізму. Прага, 1928. С. 69.

8 Там же. С. 111.

9 Донцов Д. Нациіоналізм. Львів, 1926. С. 16.

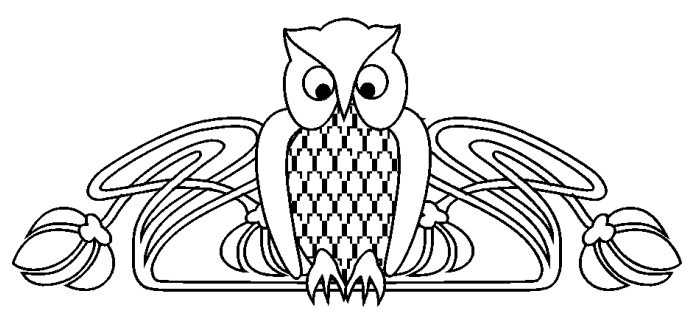

дентам достаточно высоки. Большинство фирм и учреждений предпочитают получать «готовых» специалистов с опытом работы, если не по специальности, то в близкой области или с навыками профессиональной деятельности, свидетельствующими о способности человека быстро осваивать новые знания и профессиональные требования. С другой стороны, самих молодых специалистов часто не устраивают условия труда и величина зарплаты ${ }^{1}$.Эти новые реалии требуют научного осмысления и специального исследования в силу нестандартности самого пути перехода России к обществу рыночного типа и определяемой этим специфики социальных процессов. Успешность разрешения данного объективного противоречия между расширением возможностей удовлетворения профессионально-образовательных потребностей молодежи и сокращением вероятности трудоустройства в соответствии с полученным дипломом в значительной степени определяется жизненной стратегией индивида ${ }^{2}$.

Особенно это важно для тех групп населения, которые вступают в трудовую жизнь, определяют свои профессиональные предпочтения. К таким группам, безусловно, относится студенческая молодежь. Высокий уровень образования сам по себе уже не является предпосылкой для успешной самореализации молодого человека. В условиях повышенной конкуренции, существующей в современном российском обществе, наибольшего успеха добивается тот выпускник, который уже имеет опыт профессиональной деятельности. Поэтому студенты изменяют модель достижения 
жизненных перспектив путем сокращения усилий, затрачиваемых на учебу и получение диплома, перестающего гарантировать доступ к социально привилегированным позициям, в пользу получения профессионального опыта в сфере вторичной занятости.

Анализ ситуации на рынке труда г. Саратова показывает, что выпускнику высшего учебного заведения довольно сложно найти работу. Отчасти поэтому многие молодые специалисты, еще, будучи студентами, вынуждены подрабатывать для того, чтобы к окончанию вуза накопить практический опыт и определиться с будущим местом работы. В силу актуальности трудоустройства выпускников вузов Центр региональных социологический исследований (ЦРСИ) СГУ им. Н.Г. Чернышевского на протяжении двух лет проводит мониторинг по данной проблеме. В ходе последнего опроса ${ }^{3}$ выявилось, что 75\% опрошенных выпускников Саратовского государственного университета подрабатывали во время учёбы. Причем среди гуманитариев подрабатывали 84\% студентов. Среди пятикурсников технического профиля подрабатывали чуть меньше - 77\%. Среди студентов естественнонаучных специальностей - 65,5\%. 36\% старшекурсников СГУ имели вторичную занятость на момент опроса. По данным опросов студентов российских вузов, опубликованных социологами, работающих также оказалось около половины. Почти $20 \%$ студентов имеют постоянную работу с недельной загрузкой свыше 30 часов. Более четверти студентов работают в режиме полной рабочей недели. От первого к выпускному курсу занятость возрастает ${ }^{4}$.

Определяя основные мотивы поиска дополнительного заработка, студенты акцентировали «финансовые трудности» $(47 \%)$, стремление к экономической независимости $(40 \%)$, желание получить опыт работы (30\%), самоутвердиться $(18,2 \%)$. По 9\% опрошенных ответили, что думают, о будущем и возникли семейные трудности. При этом среди юношей подрабатывали 86\%, а среди девушек - 66\%. Таким образом, вторичная занятость каждого второго студента - это не только временная работа, позволяющая удовлетворить финансовые потребности, но и стартовая площадка в начале трудового пути, возможность самореализоваться и продолжить трудовую деятельность с дальнейшей перспективой.

Как правило, работа студентов носила временный характер (70\%), 22\% опрошенных работали постоянно и 8,6\% имели разовое место работы. Среди тех, кто работал на постоянной работе, 44\% респондентов надеются остаться на прежнем месте, с перспективой карьерного роста, 29\% опрошенных студентов рассчитывают получить другую работу, близкую к своей специальности, $17 \%$ респондентов связывают свою трудовую деятельность с нынешним местом работы, 8\% опрошенных планируют устроиться на другую работу и $1,9 \%$ респондентов думают остаться на этом месте, так как сложно найти другую работу.

Так или иначе, независимо от того, работают студенты или нет, у них существуют свои представления о возможности устроиться на хорошую работу. 59\% опрошенных считают, что это сложно, $41 \%$ ответили, что это будет легко. Для большинства респондентов, наличие связей при устройстве на работу является основным фактором. Опрос показал, что среди тех, кто при поиске работы надеется на объявления и публикации в СМИ как источник информации, доминируют выпускники естественно-научных специальностей (почти 45\%), в то время как среди студентов технических специальностей таких 33\%, среди гуманитарных - 22\%. Гуманитарии больше других ориентированы на знакомых (60\%), среди «технарей» и «естественников» таковых меньше - 10 и $30 \%$ соответственно. Выпускники технических специальностей больше других рассчитывают на друзей (42\%), среди гуманитариев эта доля $33 \%$, среди «естественников» - 25\%. Последняя категория студентов больше других ориентирована на помощь родителей при трудоустройстве (67\%). Среди выпускников естественно-научных специальностей на это уповает каждый третий, среди гуманитариев - никто.

При интерпретации понятия «успех в жизни» 57,7\% выпускников сделали акцент на самореализации, на своём призвании. $40,9 \%$ опрошенных считают, что добиться успеха значит создать благополучную семью, 39,6\% связывают успех с карьерой. 22,1\% опрошенных ответили, что заработав «кучу денег», можно стать успешным человеком. $8,1 \%$ опрошенных считают, что добиться успеха означает получить власть, 7\% ответили « быть счастливым человеком».

Характеризуя свое представление о хорошей работе, 31\% выпускников указывали на высокую зарплату. $68 \%$ опрошенных предполагают, что величина их заработной платы будет от 8 до 16 тысяч рублей, каждый третий ориентирован на сумму заработка, превышающую 16000 рублей. Таким образом, молодёжь вполне реально оценивает свой будущий доход. Однако выпускники, имеющие опыт работы по специальности, ориентированы на будущую заработную плату в объеме от 8 до 16 тысяч рублей. Среди не имеющих такого опыта доминирует предполагаемая величина заработка более 16 тысяч рублей. Иными словами, опыт работы оказывает серьезное влияние на представления о будущем доходе: чем меньше опыт работы по специальности, тем больше молодые специалисты стремятся к завышенному размеру своей будущей зарплаты.

На втором месте по распространенности признаков хорошей работы оказалась возможность самореализации в профессинальной сфере, карьера (24\%). На третьем - хорошие условия труда (19\%). Далее, в порядке значимости, следовали соответствие специальности (11\%), престиж- 
ность и достаточно высокая должность (по 6\%), собственное, интересное, любимое дело, хороший коллектив. Для хорошего трудоустройства, по мнению выпускников, главным условием выступают высокий уровень профессионализма (28\%), связи $(27 \%)$, наличие диплома о высшем образовании (21\%), желание получить работу (24\%).

Однако лишь $16 \%$ опрошенных подрабатывавших выпускников работали по время учебы по специальности, у $31 \%$ работа была лишь отчасти связана с будущей профессией. 53\% - подрабатывали не по специальности. Среди всех, кто на момент опроса не нашел работу по специальности, 31,5\% гуманитариев, 34\% выпускников естественно-научных и $34,7 \%$ технических специальностей. Иными словами, среди гуманитариев только $15 \%$ студентов к выпуску имели постоянную работу по специальности. Среди студентов технического профиля таковых оказалось еще меньше - $10,4 \%$. И только в естественно научном направлении доля практически трудоустроенных по специальности оказалась выше - 23,6\%.

Только $66 \%$ от числа опрошенных считают, что выбранная ими специальность будет востребована на рынке труда в ближайшем будущем. 70\% студентов отмечали, что они не имеют гарантий трудоустройства после окончания вуза, 51\% студентов считают себя не совсем готовыми к трудовой деятельности и всего лишь 29\% опрошенных имеют полное представление о своей будущей работе. Эти данные характерны и для выпускников из других регионов, также отмечающих сложность трудоустроиться по специальности, которая будет востребована и хорошо оплачиваема 5 .

Среди факторов, которые, по мнению выпускников, способствуют трудоустройству по специальности, доминирует интерес к ней $(68,6 \%$ опрошенных). На втором месте - тот факт, что уже удалось найти работу по специальности (49\%). На третьем месте- -условия труда $(39,2 \%)$. $13,7 \%$ опрошенных считают, что их специальность пользуется спросом на рынке труда. По 7,8\% респондентов ответили, что полученная специальность престижна и возможен карьерный рост. Если обратить внимание на направления специализации, то на высокую заработную плату в наибольшей степени ориентированы специалисты в области естественных наук (40,5\%), на втором месте - «технари» (почти 32\%), на третьем - гуманитарии (почти 28\%). Последняя категория студентов больше других ориентирована на высокую должность $(37,5 \%)$. Среди выпускников технических и естественно-научные специальностей таких соответственно 33 и 29\%. Среди тех, кто больше всего ценит престижность будущей работы по специальности, доминируют «технари» $(40 \%)$. На карьерный рост больше других нацелены выпускники естественно-научные специальностей $(36,6 \%)$. Они же больше других ценят соответствие работы избранной специальности (38\%). Среди гуманитариев это ценят 34\% опрошенных, среди «технарей» $-28 \%$. Последние больше других ориентированы на хорошие условия труда $-36 \%$.

В ходе опроса выяснилось, что $61 \%$ выпускников сохранили интерес к выбранной специальности, 8,7\% - считают, что это их призвание. $21 \%$ выпускников выказали полное безразличие к полученной специальности, 5 \% так и не смогли определиться с отношением к ней. Это оказалось тесно взаимосвязанным со вторичной занятостью студентов - старшекурсников. Так, среди тех, кто почувствовал, что избранная специальность - это его призвание, 90\% подрабатывали либо по специальности, либо в смежных видах деятельности. Среди тех, кто сохранил интерес к своей будущей профессии, по специальности или «рядом» работали во время учебы $54 \%$. Среди тех, у кого будущая профессия не вызывает энтузиазма, по специальности подрабатывали только $36,5 \%$. Среди тех, кто испытывает к своей профессии негативные эмоции, по специальности не подрабатывал никто. Иными словами, чем больше студентам нравится будущая профессия, тем чаще они стараются подрабатывать по специальности. И наоборот, работа во внеучебное время по специальности способствует ее большей значимости для выпускников.

Опыт практической работы увеличивает для молодого человека ценность его профессии и во многом предопределяет его трудовые стратегии. Так, среди выпускников, считающих, что полученная специальность - это их призвание, 56\% точно планируют остаться на своей нынешней работе, $44 \%$ надеются остаться и строить карьеру. Из тех, которые считают работу по специальности интересной, только $11 \%$ уверены, что останутся работать на этом рабочем месте. 54\% - только надеются остаться и строить карьеру, 34\% надеются получить другую работу, близкую к своей специальности. Среди тех, кого не интересует будущая профессия, 75\% планируют устроиться на другую работу не по специальности. Только $25 \%$ допускают, что останутся на прежнем рабочем месте, так как сейчас сложно найти работу. Иными словами, для последней категории выпускников работа будет, по - прежнему, носить вынужденный характер. Более того, чем больше выпускники увлечены своей будущей профессией, тем выше, но осторожнее, они оценивают свои возможности трудоустройства по специальности. Возможно потому, что большая часть тех, кто работал, уже знакомы с данным сектором рынка труда, с теми требованиями, которые необходимы при трудоустройстве, больше знакомы со стратегией трудоустройства, чем те, кто не пытался работать по специальности и не имеет никакого представления об этом.

Таким образом, интерес к специальности это очень важный фактор, который определяет дальнейшую стратегию трудовой деятельности молодежи. Чем больше нравится полученная 
специальность, тем легче выпускники оценивают своё будущее трудоустройство, тем больше ориентация на профессиональную самореализацию и карьерный рост. Особенно в этом помогает опыт вторичной занятости по специальности, который способствует более реалистичному отношению к своей будущей трудовой деятельности. Сегодня работа для студента - получение практического профессионального опыта, новых знаний, ускоряющих процесс их профессионального становления и последующего трудоустройства; ознакомление с условиями работы в различных организациях, что помогает выпускникам формироваться как работникам, выбирать место постоянной работы после окончания учебы, заинтересовать собой работодателя. Трудовые предпочтения саратовских выпускников, свидетельствуют о высоких адаптационных способностях сегодняшней молодёжи. Это дает основания ожидать дальнейшего роста численности работающих студентов, актуализации их выхода на рынок труда, предопределяет потребность в повышении роли вузов в организации вторичной занятости студентов по специальности, стимулировании интереса к своей будущей профессии и повышении эффективности

УДК 316.334 .52 (5)

\section{ФИНАНСОВАЯ ГРАМОТНОСТЬ РОССИЙСКИХ СТУДЕНТОВ}

\section{А.А. Воронов}

Саратовский государственный университет

E-mail: DylnovGV@info.sgu.ru

В статье ставится проблема повышения финансовой грамотности студентов, по результатам социологического исследования дается оценка их знаний, умений и навыков в сфере финансов, анализируются основные теоретические и практические аспекты финансовых стратегий студентов, их планов и опыта относительно финансовых услуг.

Ключевые слова: финансовая грамотность, студенты, опыт пользования банковскими услугами, финансовая активность.

\section{Financial Literacy of the Russian Students.}

\section{A.A. Voronov}

The article is focused the problem of the students' level of knowledge increasing. Using the materials of the social research, students' skills and knowledge in the financial sphere are estimated. The main theoretical and practical aspects of the finance students' strategies, their plans and experience concerning financial services were analyzed.

Key words: financial literacy, students, banking service experience, financial activity.

Уровень финансовой грамотности российского населения в настоящее время чрезвычайно проведения производственной практики в тесном контакте с будущими работодателями молодых специалистов.

\section{Примечания}

1 Федотова Н.А. Профессиональный потенциал выпускников вузов // Человеческие ресурсы. 1999. № 1, 2. C $14-16$.

2 Чупров В.И. Молодежь в общественном воспроизводстве.// Социологические исследования. 1998. № 3. С. 95.

3 В ходе исследования, проведенного в рамках ЦРСИ СГУ в 2009 г., по целевой выборке было опрошено методом анкетирования 150 выпускников Саратовского государственного университета в возрасте от 21 до 24 лет (75 юношей и 75 девушек). 33\% опрошенных - студенты 5-х курсов гуманитарной сферы, $35 \%$ - естественно-научной и $32 \%$ - представители технической сферы обучения.

4 Четвернина Т.C. Положение безработных и государственная политика на рынке труда // Вопросы экономики. 1997. № 2. С. 100.

5 Хамаганова Г.А. Региональные программы содействия занятости // Человек и труд. 2004. № 4. С. 25.

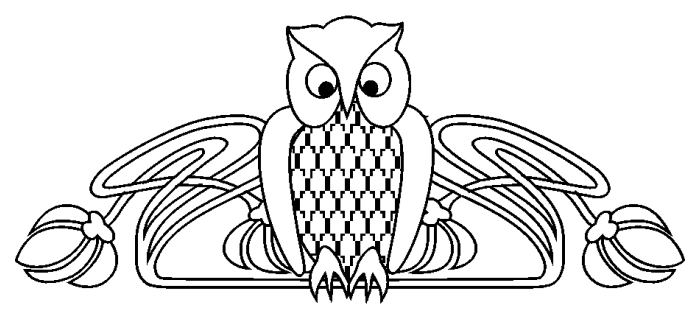

низок, и его повышение - актуальная потребность для всех участников рынка. Поэтому сегодня Министерство финансов РФ работает над составлением программы повышения финансовой грамотности. Однако это предполагает решение ряда методологических и информационных проблем, которые невозможно осуществить вне социологического ракурса.

В социологии само определение грамотности (не финансовой, а общей) вызывает много споров. Как указывает П. Робертс ${ }^{1}$, с начала 40-х гг. ХХ в. ученые не могут прийти к единому мнению, что именно считать грамотностью. В частности, грамотностью называется возможность самостоятельно оперировать записанной в символах информацией, или использование навыков общения, чтения и письма для расширения возможностей понимания мира. Однако в русле качественного определения грамотности не существует единого понимания, что заметно усложняет изучение процесса.

Национальный фонд исследований в сфере образования (National Foundation for Educational 